Viso: Cadernos de estética aplicada

Revista eletrônica de estética

ISSN 1981-4062

No 25, jul-dez/2019

http://www.revistaviso.com.br/

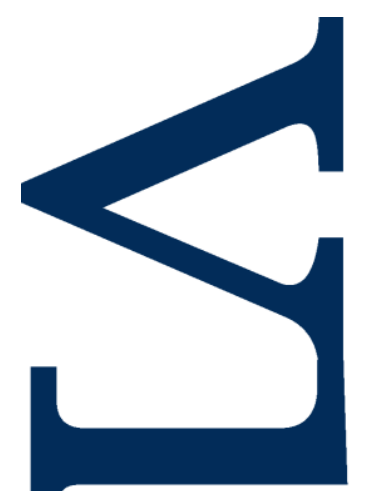

\title{
A náusea de Hamlet: uma interpretação de Hamlet segundo 0 nascimento da tragédia de Nietzsche
}

Mateus Masiero

Newton P. Amusquivar Jr. 


\section{RESUMO}

A náusea de Hamlet: uma interpretação de Hamlet segundo 0 nascimento da tragédia de Nietzsche

A partir da relação entre o personagem Hamlet e o homem dionisíaco apresentada na seção sete de $O$ nascimento da tragédia, o presente artigo pretende interpretar a tragédia homônima de Shakespeare por meio de conceitos elaborados na mencionada obra de Nietzsche. Nesse sentido, buscamos entender a peça Hamlet como uma tragédia dionisíaca moderna, que conteria em si tanto o pathos dionisíaco quanto a aparência apolínea. Assim, nós propomos uma análise nietzschiana de Hamlet por meio de elementos dados pelo próprio filósofo alemão. Nesse percurso, poderemos compreender, ainda, de maneira profunda o que significa o homem dionisíaco, a sua náusea, o seu pathos, a sabedoria dionisíaca, a necessidade da aparência apolínea, dentre outros conceitos encontrados em $O$ nascimento da tragédia.

Palavras-chave

Hamlet; Shakespeare; Nietzsche; dionisíaco; apol'íneo; tragédia

\section{ABSTRACT}

Hamlet's Nausea: an Interpretation of Hamlet according to Nietzsche's The Birth of Tragedy

From the relationship between Hamlet's character and the Dionysian man presented in the seventh section of The birth of tragedy the present paper intends to interpret Shakespeare's homonym tragedy by concepts formulated in Nietzsche's aforementioned work. We aim to understand the play Hamlet as a Dionysian modern tragedy which would contain both the Dionysian pathos and the Apollonian appearance. Therefore we propose a nietzschean analysis of Hamlet with the elements provided by the German philosopher himself. Hereupon we can also in-depth understand the meaning of certain concepts such as the Dionysian man, his nausea, his pathos, the Dionysian wisdom and the requirement of Apollonian appearance among other concepts found in The birth of tragedy.

Keywords

Hamlet; Shakespeare; Nietzsche; dionysian; apollonian; tragedy 
MASIERO, Mateus; AMUSQUIVAR JR., Newton P. "A náusea de Hamlet: uma interpretação de Hamlet segundo 0 nascimento da tragédia de Nietzsche". Viso: Cadernos de estética aplicada, v. 13, n 25 (juldez/2019), p. 108-137.

DOI: $10.22409 / 1981-4062 / v 25 i / 325$

Aprovado: 14.03.2019. Publicado: 30.12.2019.

(c) 2019 Mateus Masiero; Newton P. Amusquivar Jr. Esse documento é distribuído nos termos da licença Creative Commons Atribuição-NãoComercial 4.0 Internacional (CC$\mathrm{BY}-\mathrm{NC}$ ), que permite, exceto para fins comerciais, copiar e redistribuir o material em qualquer formato ou meio, bem como remixá-lo, transformá-lo ou criar a partir dele, desde que seja dado o devido crédito e indicada a licença sob a qual ele foi originalmente publicado.

Licença: http://creativecommons.org/licenses/by-nc/4.0/deed.pt_BR

Accepted: 14.03.2019. Published: 30.12.2019.

(C) 2019 Mateus Masiero; Newton P. Amusquivar Jr. This document is distributed under the terms of a Creative Commons Attribution-NonCommercial 4.0 International license (CC-BY-NC) which allows, except for commercial purposes, to copy and redistribute the material in any medium or format and to remix, transform, and build upon the material, provided the original work is properly cited and states its license. License: http://creativecommons.org/licenses/by-nc/4.0/ 
Em $O$ nascimento da tragédia, Nietzsche realiza uma analogia entre o homem dionisíaco e o personagem Hamlet de Shakespeare, tendo como base a relação existente entre sabedoria dionisíaca e a atuação (ou não atuação) do indivíduo. A leitura que pretendemos elaborar neste artigo é que essa analogia pressupõe uma interpretação mais abrangente por parte do filósofo em relação à tragédia Hamlet como um todo. Ao relacionar a análise de alguns dos conceitos estéticos utilizados por Nietzsche (apolíneo, dionisíaco, Unoprimordial, consolo metafísico, etc) com a análise da mencionada tragédia shakespeariana, pretendemos evidenciar quais os elementos que levaram o filósofo alemão a realizar tal analogia. Assim, nosso objetivo neste artigo será desenvolver dois pontos: mostrar que Nietzsche compreendia Hamlet como uma tragédia dionisíaca moderna; e propor uma leitura da peça de Shakespeare a partir dos conceitos presentes na mencionada obra nietzschiana.

Nos textos preparatórios para 0 nascimento da tragédia é possível notar uma ambiguidade por parte do autor em relação a Shakespeare. Nietzsche apresentava uma visão crítica da tragédia moderna, considerando-a, nas preleções Introdução à tragédia de Sófocles, como inferior à tragédia grega. Isso porque, se essa última repousa no pessimismo e no espírito da música e da lírica, com o predomínio do pathos, a primeira, por sua vez, é moralista, e tem sua origem na plasticidade da poesia épica, sendo otimista e com um predomínio da ação no lugar do pathos. Nessas preleções, Nietzsche considera as tragédias shakespearianas como romances dramatizados, e por isso são enquadradas no processo de decadência da tragédia. Igualmente, no início da conferência $O$ drama musical grego, Nietzsche considera que "na forma externa da cena de Shakespeare não se pode desconhecer o parentesco genealógico com a nova comédia ática"1 ${ }^{1}$ a qual representava uma decadência da tragédia para ele. Entretanto, na conferência Sócrates e a tragédia, proferida apenas alguns dias depois de 0 drama musical grego, o autor apresenta um posicionamento distinto do da conferência anterior, considerando que "os heróis de Shakespeare usam a dialética 
de uma maneira completamente diferente [do que nas tragédias tardias e na Nova Comédia]: sobre todos os seus pensamentos, suposições e conclusões vertem-se certa beleza e interiorização musical". ${ }^{2}$ Assim, o filósofo alemão afirma que as tragédias shakespearianas contêm uma dialética originada na música, e não na lógica, de modo que seus diálogos trágicos não eram semelhantes aos de Sócrates e a sua moralidade: "na linguagem e no delineamento dos caracteres de Shakespeare [...] podemos encontrar uma sabedoria ética diante da qual o socratismo aparece como algo indiscreto e com uma prudência infantil". ${ }^{3}$ Nietzsche deixa claro aqui que a tragédia shakespeariana não se vincula ao socratismo estético, pois ela não se funda na moralidade socrática, como este último.

É um tanto desconcertante notar essas diferentes interpretações sobre Shakespeare em um lapso de apenas alguns dias entre uma conferência e outra. No entanto, o que nos interessa destacar é que essa ambiguidade dos textos preparatórios desaparece em 0 nascimento da tragédia, obra em que o filósofo apresenta uma nova concepção acerca do dramaturgo britânico, ligada ao dionisíaco. Isso porque, nessa obra, Nietzsche reformula seu conceito acerca da tragédia, através da dualidade entre apolíneo e dionisíaco; essa nova forma de pensar a tragédia se reflete na concepção assumida pelo filósofo em relação à obra shakespeariana como um todo - o que se evidencia particularmente por meio de uma referência à obra-prima do poeta: Hamlet. Nas sessões sete e dezessete, Nietzsche trata da inação de Hamlet, comparando-o ao "homem dionisíaco" e evidenciando na personagem a náusea e a sabedoria próprias deste último.

Como compreender, pois, essa analogia entre Hamlet e o homem dionisíaco? Em que sentido essa tragédia de Shakespeare contém elementos da metafísica de artista de Nietzsche? A peça Hamlet pode ser considerada uma tragédia moderna, segundo a concepção nietzschiana? 
Para compreendermos a maneira pela qual Nietzsche caracteriza o homem dionisíaco, é inevitável tratarmos da dualidade entre dois impulsos tanto artísticos como naturais, a saber, o apolíneo e o dionisíaco. Pelo fato de tais impulsos serem não somente artísticos, mas também naturais, o autor os caracteriza a partir de manifestações fisiológicas. Assim, Apolo, deus délfico, representa o impulso da aparência, constituindo o que Schopenhauer chamou de "véu de Maia", ou seja, o principium individuationis em que a bela aparência plástica dissimula a verdadeira realidade. Nesse sentido, segundo Nietzsche, o sonho é o estado fisiológico associado ao apolíneo, pois no sonho são formadas imagens ilusórias da realidade; trata-se, dessa forma, de um estado em que somos um artista natural a produzir imagens e figuras plásticas. Por outro lado, se Apolo representa uma divinização do principium individuationis, Nietzsche utiliza a figura do deus Dionísio para caracterizar o impulso que rompe com tal princípio. Esse rompimento é um êxtase análogo ao estado de embriaguez, que é o estado fisiológico correlato ao dionisíaco; nesse êxtase, as formas cognitivas e a aparência fenomenal são transviadas, levando o indivíduo a um sentimento de terror em relação à realidade. Ao romper o principium individuationis, contempla-se a verdade da natureza, que consiste em uma unidade originária, chamada de Uno-primordial [das Ur-Eine], que contém uma constante dor, contradição e mistério; portanto, a essência metafísica do mundo está sujeita a um constante pathos, tal como a Vontade em Schopenhauer. A essa verdade da natureza é que se refere o impulso dionisíaco, isto é, o impulso do êxtase, do sair de si que expressa a dor do mundo em músicas e danças frenéticas. No entanto, o Uno-primordial, para se redimir dessa constante dor e contradição, necessita da aparência prazerosa apolínea. Esta última, enquanto endeusamento do principium individuationis, oculta a dor essencial do mundo e dispõe os homens em uma realidade fenomênica, singularizando-os em uma individualidade ilusória, responsável pela civilização. 
Como dissemos, segundo a metafísica do artista, esses impulsos naturais estão presentes também na arte, de modo que esta imita um processo presente na natureza. Assim, na arte, o elemento dionisíaco se relaciona com a poesia lírica de Arquíloco, e com a arte musical não figurada, que estimula a canção e a dança de uma multidão extasiada. Já o impulso apolíneo se manifesta artisticamente através da beleza plástica das imagens, da arte figurativa e da poesia épica de Homero. Por fim, a tragédia, por seu turno, é a arte em que ocorre uma união entre Apolo e Dionísio, uma vez que o coro descarrega o impulso dionisíaco da música na aparência apolínea de belas imagens plásticas. A tragédia, nesse sentido, tem a função metafísica de expressar a verdade da natureza dionisíaca através da aparência prazerosa apolínea:

e o fato de ele [Dionísio] aparecer com tanta precisão e nitidez épicas é efeito do Apolo oniromante que interpreta para o coro o seu estado dionisíaco, através daquela aparência similiforme. Na verdade, porém, aquele herói é - Dionísio sofredor, dos Mistérios, aquele deus que experimenta em si os padecimentos da individuação [.... ${ }^{4}$

A tragédia é capaz de descarregar o pathos do Uno-primordial em figuras belas, e por isso somos capazes de senti-lo e, ao mesmo tempo, nos redimir de sua dor por intermédio do prazer artístico. Na tragédia, o homem dionisíaco é o elemento fundamental, pois ela "tinha por objeto apenas os sofrimentos de Dionísio" ${ }^{5}$, de forma que todos os heróis trágicos nada mais são do que máscaras desse deus: "todas as figuras afamadas do palco grego, Prometeu, Édipo, e assim por diante, são tão somente máscaras daquele proto-herói, Dionísio". ${ }^{6}$ Assim, no herói trágico o pathos do Uno-primordial aparece individualizado na forma de um homem dionisíaco capaz de usar máscaras apolíneas.

Desse modo, a analogia entre Hamlet e o homem dionisíaco indica que o herói trágico shakespeariano é, também, uma máscara de Dionísio. Hamlet traz consigo aquele pathos do Uno-primordial já mencionado, o qual é notável já em sua primeira aparição na peça, em que ele se encontra mergulhado 
no luto pela morte do seu pai (o antigo rei) e inconformado com o casamento incestuoso de sua mãe com Cláudio, pouco tempo depois da morte do rei. Podemos perceber, no primeiro diálogo de Hamlet com sua mãe e seu tio, que diante da morte existe uma contraposição entre a verdade da natureza e a aparência da civilização e das instituições sociais. A rainha pede ao filho que deixe as vestimentas lutuosas e lembra a ele que a morte é algo comum. Hamlet concorda com essa constatação, mas, quando a mãe questiona o porquê de parecer que a morte do pai o afeta tanto, o príncipe afirma: "Parece, minha senhora? Não: é! Não sei 'parecer!"'." Para Nietzsche, toda a organização social e política, com seus cargos, convenções e hierarquias, é fruto da individualidade ilusória que constitui a aparência apolínea. 0 êxtase dionisíaco, ao romper tal ilusão, suplanta também todas as convenções sociais: "Agora o escravo é homem livre, agora se rompem todas as rígidas e hostis delimitações que a necessidade, a arbitrariedade ou a 'moda impudente' estabeleceram entre os homens". ${ }^{8}$ Para aquele que constatou o caráter ilusório de toda a individuação, tais convenções que nela vigoram são tão desprezíveis quanto ela própria. Hamlet não vê sentido em observar as regras de etiqueta referentes à morte; seu luto possui um sentido muito mais profundo: "o que dentro de mim sinto supera todas as exterioridades que nada mais são do que os atavios e as galas da dor!". ${ }^{9}$ Para a rainha, o luto é apenas um costume; para ela, Hamlet deve abandonar tal postura para, assim, se enquadrar na ordem social e racional das coisas, seguindo o costume de não exceder a medida (característica apolínea) saudável do luto. Nessa mencionada cena, toda a corte está em festa pelo casamento e coroação do novo rei, resplandecendo alegremente o júbilo desse triunfo da vida: as núpcias. Em meio a essa luminosa festividade, Hamlet destoa de tudo e de todos ao exteriorizar o sofrimento e a repulsa pelas práticas sociais que o circundam. Nietzsche considera que a individuação, sendo associada ao despedaçamento do deus Dionísio, deve ser entendida como o verdadeiro sofrimento dionisíaco e, portanto, como "fonte e causa primordial de todo sofrer, como algo em si rejeitável". ${ }^{10}$ Hamlet 
apresenta esse mesmo sofrimento e rejeição à individuação, representada nessa cena pelas convenções sociais da corte dinamarquesa. Portanto, há um conflito entre a postura do príncipe e a da corte: esta tende a priorizar aspectos da cultura apolínea, enquanto aquele ostenta o pathos da dor primordial, manifestado na forma de repulsa pela individuação.

Tal conflito será recorrente em toda a peça. Segundo Jan Kott, a atitude de Hamlet "lembra o que todos gostariam de esquecer" ${ }^{11}$, sendo, portanto, uma presença extremamente desagradável a outrem; seu discurso provocativo visa sempre a romper a ilusão prazerosa onde todos preferem se esconder do horror da realidade. 0 mesmo potencial do discurso hamletiano é percebido por Harold Bloom, o qual afirma que o príncipe desperta a nossa consciência, "nos faz ver o mundo de uma maneira nova, mais profunda do que, normalmente, estamos dispostos a fazê-lo". ${ }^{12} 0$ único personagem que constitui exceção dentre os alvos perseguidos pela argúcia de Hamlet é Horácio, o seu fiel amigo, e que representa a honestidade, a amizade desinteressada. Horácio é uma espécie de contraponto da falsa amizade de Rosencrantz e Guildenstern, os quais são facilmente subornados pelo rei e até mesmo o ajudam na vigilância e nas ciladas preparadas contra o príncipe. Esse conflito entre a postura de Hamlet e a dos demais personagens se acentua após a revelação feita pelo fantasma de seu pai acerca da verdade sobre a sua morte, que fora até então ocultada de todos. Diante dessa revelação, o príncipe é exortado a vingar a morte do pai, ou seja, é intimado à ação; e, mais do que uma vingança, esse agir possui, como veremos, uma espécie de sentido metafísico de ordenar o cosmos, recolocar o mundo nos eixos dos quais fora removido. A partir desse acontecimento, que figura nas últimas cenas do primeiro ato, a tensão entre o saber dionisíaco e a necessidade de agir está irremediavelmente instaurada e perturbará nosso herói ao longo dos próximos três atos da tragédia. Nisso consiste a náusea de Hamlet, como veremos. 
A analogia entre o homem dionisíaco e Hamlet não se refere apenas à expressão da dor do Uno-primordial em um herói trágico, mas também à sabedoria do príncipe, uma vez que tal saber se refere mais à essência profunda das coisas do que à mera aparência; é uma sabedoria dionisíaca, semelhante à que Nietzsche descreve na seção sete de $O$ nascimento da tragédia. O filósofo destaca que a dualidade entre apolíneo e dionisíaco acarreta também dois tipos distintos de sabedoria: se, de um lado, Apolo traz consigo a sabedoria presente no templo de Delfos, a famosa formulação "conhece-te a ti mesmo"; de outro, Dionísio apresenta a "sabedoria do Sileno", que não é bela e nem otimista - ao contrário, ela consiste em um grande horror e no mais árido pessimismo. Essa sabedoria de Sileno é narrada na seção três da mencionada obra, em que o sátiro diz:

Estirpe miserável e efêmera, filhos do acaso e
do tormento! Por que me obrigas a dizer-te o
que seria para ti mais salutar não ouvir? 0
melhor de tudo é para ti inteiramente
inatingível: não ter nascido, não ser, nada ser.
Depois disso, porém, o melhor para ti é logo
morrer. $^{13}$

Trata-se de vislumbrar, por um momento, a verdadeira realidade e romper a aparência apolínea, desvelando a natureza em toda sua crueldade e horror. A sabedoria dionisíaca proveniente desse processo consiste em um excesso de pathos, o qual se opõe à realidade cotidiana, tendo em mira a noção de que tudo que existe deve necessariamente se destruir. Nessa contemplação da verdadeira realidade, há um sentimento de unidade com a natureza, em que ocorre um despedaçamento do indivíduo. O êxtase dionisíaco, ao aniquilar os limites da existência individual, contém em si um elemento letárgico, separando por um abismo a realidade cotidiana da dionisíaca. Após sentir a reconciliação com a unidade primordial, o retorno à individuação acarreta um sentimento de nojo pela mesma; tão logo a realidade cotidiana reingressa na consciência, o saber dionisíaco, que lá permanecera, mata a ação do indivíduo, uma vez que reconhece essa realidade 
cotidiana em que agora está como mera ilusão. Diante da náusea gerada por essa constatação, corre-se "o perigo de ansiar por uma negação budista do querer" ${ }^{14}$

Segundo Nietzsche, essa sabedoria dionisíaca é transmitida no pathos da música, que é descarregado na linguagem poética, dando origem à poesia lírica. Esse processo de transfiguração do pathos dionisíaco em linguagem que ocorre na poesia lírica pode ser apontado como o gérmen da união entre dionisíaco e apolíneo, união esta que resultará depois no nascimento da tragédia. Isso porque a poesia lírica, ao se manifestar por meio da canção popular, agrega uma multidão em êxtase, formando um coro que simula o estado natural dionisíaco. Nietzsche considera que esse coro é o responsável pelo surgimento da tragédia, pois ele suspende [aufgehoben] a ilusão da civilização, através do reencontro com a unidade natural:

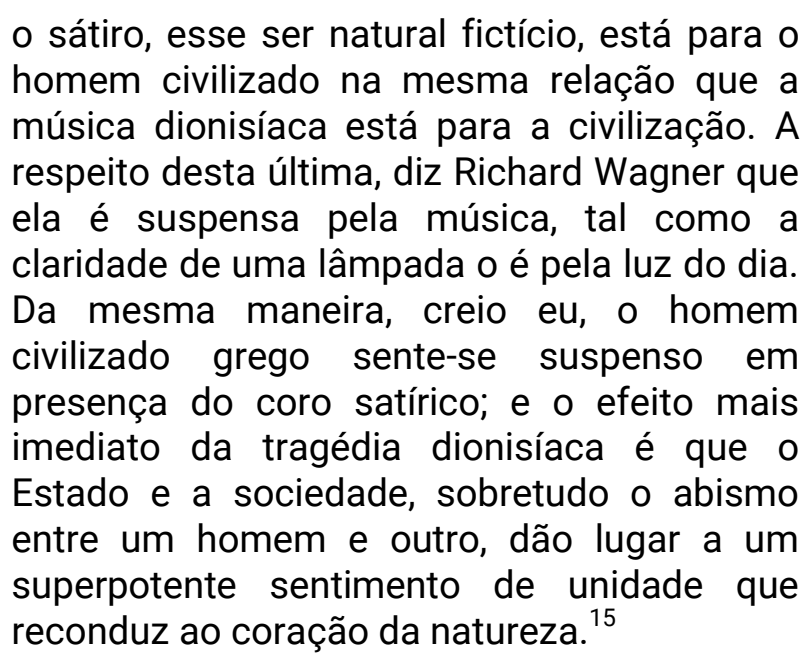

Já observamos, acima, que há um estreito vínculo entre a individuação apolínea e as convenções sociais e políticas, sendo que estas são fruto daquela; e que o êxtase dionisíaco rompe tal individuação, propiciando uma dissolução do indivíduo em meio ao todo. Essa ideia é retomada aqui: percebe-se que a unidade com a natureza, proporcionada pelo coro trágico, está sempre subjacente à civilização, de forma que entre a verdade da natureza e a ilusão da civilização existe uma relação tal como a relação entre coisa em si e fenômeno, respectivamente. ${ }^{16} \mathrm{Na}$ medida em que o coro restabelece a unidade natural, então é possível ter, com a completa ausência 
da civilização (com suas instituições sociais e políticas) e da ilusão da individuação, o consolo metafísico de que a vida é cheia de alegria, apesar do constante tormento do devir. Isso porque tal coro satírico é composto por seres naturais, que estão sempre "por trás de toda civilização, e que, a despeito de toda mudança de gerações e das vicissitudes da história dos povos, permanecem perenemente os mesmos". ${ }^{17}$

É exatamente ao tratar dessa questão acerca do consolo metafísico propiciado pelo coro que Nietzsche realiza a analogia entre Hamlet e o homem dionisíaco. O príncipe da Dinamarca é um herói trágico, que vive uma intensa oposição entre verdade da natureza (na forma de uma profunda angústia diante do absurdo da existência) e ilusão da civilização (isto é, o mundo empírico das instituições sociais que o cerca) e, portanto, apresenta o mesmo desprezo pela última que o homem dionisíaco. Nietzsche se vale do personagem Hamlet como exemplo para auxiliar a compreensão da formação individual de um herói trágico, e através disso ele visa desvendar o nascimento da tragédia. Ainda na seção sete, encontramos a seguinte passagem:

Nesse sentido, o homem dionisíaco se assemelha a Hamlet: ambos lançaram alguma vez um olhar verdadeiro à essência das coisas, ambos passaram a conhecer e a ambos enoja atuar; pois sua atuação não pode modificar em nada a eterna essência das coisas, e eles sentem como algo ridículo e humilhante que se lhes exija endireitar de novo o mundo que está desconjuntado. ${ }^{18}$

E, todavia, o que se exige de Hamlet é justamente que ele endireite o mundo desconjuntado: "O mundo está fora dos eixos. Oh! Maldita sorte!... Por que nasci para colocá-lo em ordem?". ${ }^{19}$ Como já adiantamos acima, mais do que vingar o assassinato de seu pai, ele deve reordenar o cosmos, de modo que sua missão possui como que um sentido metafísico. Sentido esse no qual Hamlet descrê, conforme Nietzsche observa. Portanto, o que tolhe a atuação do personagem não é (como grande parte da crítica especializada foi levada a pensar) um excesso de consciência, o qual the colocaria 
defronte uma infinidade de opções. Para Nietzsche, tanto Hamlet quanto o homem dionisíaco sentem-se enojados diante da obrigação de atuar, uma vez que compreenderam o caráter imutável e horroroso da "eterna essência das coisas"; eles entenderam que é inútil e degradante serem chamados a corrigir o mundo. Em outros termos, o príncipe dinamarquês possui a sabedoria de Sileno, a consciência que rompe a individuação apolínea e contempla o horror da existência em toda sua verdade dolorosa, acarretando a inércia do indivíduo:

O conhecimento mata a atuação, para atuar é preciso estar velado pela ilusão - tal é o ensinamento de Hamlet e não aquela sabedoria barata de João, o Sonhador, que devido ao excesso de reflexão, como se fosse por causa de uma demasia de possibilidades, nunca chega à ação; não é o refletir, não, mas é o verdadeiro conhecimento, o relance interior na horrenda verdade, que sobrepesa todo e qualquer motivo que possa impelir à atuação, quer em Hamlet, quer no homem dionisíaco. $^{20}$

Não se trata de quanto se reflete, mas de como se dá tal reflexão; é o tipo de conhecimento que está em jogo. Não é por um excesso de reflexão racional, mas sim por uma consciência acerca do horror da existência. Nesse sentido, podemos dizer que não é propriamente uma questão de indecisão, mas de negação: Hamlet se nega a agir, e se nega porque compreende que tal ação é inútil diante da imutabilidade da essência das coisas. Vingar a morte do pai, assassinar o rei corrupto e sua corte, nada disso resolve o problema essencial da condição humana; não restabelece a ordem perdida, pois sequer existe uma ordem a ser restaurada. São apenas questões pontuais e sintomáticas: não se referem à essência do problema, que é o próprio horror da existência. Aqui temos um ponto de ruptura em relação a grande parte dos estudiosos de Hamlet, os quais tendem a ver a inação do príncipe como dúvida e hesitação. Por essa leitura nietzschiana que fazemos, não se trata de dúvida, mas de negação da ação.

Ao afirmar que "para atuar é preciso estar velado pela ilusão", Nietzsche deixa clara a relação entre a inação e o 
conhecimento dionisíaco, assim como entre a ação e o conhecimento apolíneo. Este último não conduz à negação da vontade, ao contrário: a ilusão é condição para a atuação; estar velado por ela é precisamente o único meio pelo qual se pode viver e agir. Essa é a razão, inclusive, pela qual os gregos antigos criaram o mundo de deuses olímpicos, com o qual interpõem a verdade dolorosa. ${ }^{21}$ Já o êxtase dionisíaco traz uma consequência: embora traga $o$ deleite momentâneo da reconciliação com a natureza, tal sentimento é passageiro e, ao retornar à realidade cotidiana, o indivíduo se vê diante da consciência de todo o horror e absurdo da existência; isso o enoja e tal nojo mina sua vontade. É a isso que chamamos náusea de Hamlet - o que tolhe o príncipe é o fato de ele ser portador de um conhecimento dionisíaco, é a náusea proveniente do conhecimento da verdade. De outro modo, não haveria hesitação de sua parte, como a que podemos perceber no monólogo que se segue à encenação da morte de Hécuba:

Contudo, eu, estúpido e turvo velhaco, permaneço como um néscio sonhador, indiferente à minha própria causa, nada sabendo dizer; não, nem a favor de um rei, sobre cujos bens e vida preciosíssima caiu uma conspiração maldita. Serei um covarde? ${ }^{22}$

Igualmente, após interpelar o capitão das tropas norueguesas que rumam resolutamente para conquistar territórios sem importância na Polônia, em uma batalha desprovida de sentido, Hamlet diz consigo:

Que papel estou, então, fazendo, eu que tenho um pai assassinado e uma mãe maculada, fortes acicates para minha razão e para meu sangue e deixo que tudo durma em paz? Enquanto que, para minha vergonha, estou vendo a morte iminente desses vinte mil homens que, por um capricho e uma ilusão de glória, correm para os túmulos, como se fossem leitos e pelejam por um pedaço de terra tão diminuto que não oferece espaço aos combatentes para manter a luta e nem sequer é uma tumba bastante profunda para enterrar os mortos. ${ }^{23}$ 
Ora, como já destacamos, segundo Nietzsche, esse conhecimento originado pela união com o dionisíaco, uma vez reinserido no mundo da aparência, mata a atuação, e para atuar é preciso estar velado pela ilusão. Nesse excerto acima, podemos perceber que, para Hamlet, o que move tais soldados é a ilusão, ou seja, um conjunto de convenções sociais e políticas pelas quais se cria uma imagem acerca da glória e dos demais valores. Se considerada com mais profundidade, por uma consciência mais ampla, como é a de Hamlet, a situação revela-se absurda; mas, velados pela ilusão das recompensas honoríficas da realidade empírica, os soldados marcham para a morte sem qualquer indício de hesitação. Já o príncipe dinamarquês, tendo plena consciência do caráter ilusório da individuação, continua a se negar a cumprir seu dever imposto.

A negação em agir do personagem shakespeariano faz-se notar no decorrer de quase toda a peça e, segundo Bloom, ela deve ser sempre entendida como sinônimo de consciência. ${ }^{24}$ Hamlet se debate contra seu dever, procurando evitá-lo, pois sabe que é impossível corrigir o mundo, e o sentimento de nojo está sempre presente em suas falas e suas atitudes. 0 príncipe afirma ter perdido a alegria e abandonado todas as ocupações habituais: "sinto-me com uma disposição de espírito tão sombria que este glorioso recinto, a Terra, até me está parecendo um promontório estéril" ${ }^{25}$, diz ele, denotando o quanto a realidade cotidiana o desgosta e faz com que perca a disposição para suas atividades costumeiras. Em seguida, ao discorrer acerca da beleza plástica (que é uma característica apolínea, vale lembrar) das diversas qualidades do mundo e das faculdades racionais (apolíneas novamente) do homem, afirma que nada disso o satisfaz, nada abate sua propensão à apatia. No entanto, talvez o momento crucial da tragédia, no qual a disposição ascética se mostra de modo mais acentuado, seja o famoso monólogo do "ser ou não ser". Ao ponderar acerca das dificuldades que o mundo nos opõe, Hamlet destila sua amargura, cogitando o suicídio como forma de se libertar da individuação: 
Ser ou não ser, eis a questão! Que é mais nobre para o espírito: sofrer os dardos e setas de um ultrajante fado, ou tomar armas contra um mar de calamidades para por-lhes fim, resistindo? Morrer... dormir; nada mais! E com o sono, dizem, terminamos o pesar do coração e os mil naturais conflitos que constituem a herança da carne! ${ }^{26}$

Percebe-se que, para ele, a vida terrena é sinônimo de contrariedade, sendo a morte uma escapatória para todas as angústias - afinal, seguindo a lógica de Sileno, se o mais desejável (nunca ter nascido) é inatingível, então o melhor bem possível de ser alcançado é logo morrer. Viver é ter que escolher entre suportar fados ultrajantes ou enfrentar o "mar de calamidades". Porém, para esse enfrentamento, é preciso agir, e a perspectiva da ação faz com que Hamlet hesite, pois, intimamente, ele sabe o que isso realmente implica; trata-se da disposição ascética originada pela sabedoria do homem dionisíaco, a qual considera degradante ser chamado para agir, uma vez que conhece a verdadeira essência imutável de todas as coisas. Melhor seria deixar de ser, morrer. Entretanto, a morte ainda traz um possível perigo: "Talvez sonhar! Sim, eis aí a dificuldade! Porque é forçoso que nos detenhamos a considerar que sonhos possam sobrevir, durante o sono da morte $[. . .]^{\prime 2}{ }^{27} \mathrm{O}$ sonho é o estado fisiológico correspondente aos impulsos apolíneos, como dissemos acima. 0 que percebemos aqui é o receio por parte do príncipe de que nem mesmo a morte seja uma libertação completa da ilusão apolínea que tanto o enoja; mesmo com o fim da vida, talvez ainda se possa sonhar, o que constitui um fator a mais para que Hamlet hesite diante do suicídio. Isso ressalta o quanto ele sente repulsa pela individuação, o quanto a vida empírica the causa náusea. Na sequência do monólogo, ele afirma:

E é assim que a consciência nos transforma em covardes e é assim que o primitivo verdor de nossas resoluções se estiola na pálida sombra do pensamento e é assim que as empresas de maior alento e importância, com tais reflexões desviam seu curso e deixam de ter o nome de ação... ${ }^{28}$ 
Podemos bem inferir que a consciência à qual Hamlet se refere nessa passagem é a consciência de homem dionisíaco, que rompe com a ilusão apolínea, mas, ao retornar a ela, causa a náusea e a inação. Trata-se da disposição ascética em sua mais deliberada confissão.

Outra característica interessante que podemos extrair desse famoso monólogo é o seu aspecto notadamente lírico. Como já destacamos, Nietzsche, em Sócrates e a tragédia, enxerga nos diálogos shakespearianos uma dialética que possui uma interiorização musical. Desse modo, podemos intuir que tal dialética desempenha o papel que o coro exercia na tragédia ática. Embora não haja coro na peça de Shakespeare, isso não significa, necessariamente, que o efeito do coro esteja ausente. Em Hamlet, essa musicalidade pode ser percebida, por exemplo, nos monólogos do protagonista e nas canções de Ofélia. Nesse sentido, o príncipe se assemelha a um poeta lírico, cujos monólogos transmitem uma beleza poética que descarrega o pathos musical dionisíaco, materializando em imagens toda a angústia e contradição vivenciadas pelo personagem.

Sobre essa questão, cabe notar alguns apontamentos que Nietzsche faz nas duas seções imediatamente anteriores à seção sete, e que apresentam importantes premissas do raciocínio presente nesta última. Ao analisar a poesia lírica de Arquíloco (considerada pelo filósofo como gérmen da tragédia, como vimos), Nietzsche considera que não se trata de expressão da subjetividade do poeta. Na verdade, Arquíloco é apenas o canal pelo qual Dionísio se manifesta, de modo que a poesia deve ser entendida como expressão do Ser primordial, e não da individualidade do poeta. Essa expressão do sentimento dionisíaco, aliada à plasticidade apolínea, produz "como que centelhas de imagens, poemas líricos, que em seu mais elevado desdobramento se chamam tragédias e ditirambos dramáticos". ${ }^{29}$ Tais imagens são "tão-somente objetivações diversas" ${ }^{30}$ do eu do próprio poeta; porém, esse "eu" não se refere ao poeta enquanto indivíduo, isto é, enquanto homem empírico-real, a viver no principium individuationis. Nesse 
momento em que está a produzir as "centelhas de imagens" que são os poemas líricos, o poeta se encontra em seu êxtase dionisíaco, durante o qual os limites da existência individual foram suprimidos pelo sentimento de unidade com o todo. Desse modo, o "eu" que se manifesta na poesia é, na realidade, o Uno-primordial, o qual é traduzido em linguagem apolínea. Nesse sentido, podemos apontar um processo análogo no lirismo dos monólogos de Hamlet, uma vez que ele pode ser visto como um homem dionisíaco (segundo a afirmação do próprio Nietzsche na seção sete), e que a poesia lírica pode ser considerada "como a fulguração imitadora da música em imagens e conceitos". ${ }^{31}$ As palavras ditas pelo príncipe nesse e nos demais monólogos transbordam lirismo e, com sua interiorização musical, como que mimetizam aquela expressão do Uno-primordial que apenas a música pode ter. Não é a subjetividade de Hamlet (enquanto indivíduo empírico) que está sendo expressa ali, mas, tal qual ocorria com Arquíloco, a expressão da dor, da angústia e do horror diante da existência. É disso que o monólogo trata, e não das indecisões de um jovem príncipe.

Voltando à seção sete de 0 nascimento da tragédia, um segundo aspecto da analogia entre Hamlet e o homem dionisíaco que podemos notar é a relação do príncipe com Ofélia, bem como o trágico destino de que esta padece. Nietzsche considera a loucura seguida de suicídio de Ofélia como simbólica do caráter terrível da existência:

$\mathrm{Na}$ consciência da verdade uma vez contemplada, o homem vê agora, por toda parte, apenas o aspecto horroroso e absurdo do ser, agora ele compreende o que há de simbólico no destino de Ofélia, agora reconhece a sabedoria do deus dos bosques, Sileno: isso o enoja ${ }^{32}$.

Com o saber dionisíaco, o indivíduo mergulha em uma experiência nauseante que pode negar não só a atuação, mas também a própria vida: tal como Hamlet, Ofélia também contemplou o horror da existência, e ambos sabem (aprenderam com Sileno) que o melhor é logo morrer. Mais do 
que isso, morrer sem transmitir o fado da existência humana, já que o melhor de tudo é nunca ter nascido. Podemos notar essa postura negadora da vida no famoso diálogo entre os dois personagens, em que o príncipe diz a sua amada: "Entra para um convento. Por que desejais ser mãe de pecadores? [...] Todos nós somos consumados canalhas; não te fies em nenhum de nós. Segue teu caminho para o convento". ${ }^{33}$ Ao contrário do preceito apolíneo de almejar a vida e morrer o mais tardar, a náusea faz com que prevaleça o preceito de Sileno de que o melhor é não ser, ou logo morrer. Hamlet não vê sentido na procriação humana; considera-a absurda e não entende a razão de ele próprio ter nascido. Pelo mesmo motivo, recomenda a Ofélia que se abstenha de ser mãe, pois o fato de ter filhos apenas multiplica o absurdo que é a existência ressaltando, assim, o quanto a náusea sofrida pelo homem dionisíaco acarreta uma negação da vida. Por sua vez, Ofélia, mergulhada na loucura de quem não suportou compreender $o$ horror da verdade, coloca fim a sua própria vida, ainda virgem, ratificando a preponderância da sabedoria de Sileno. Eis o que há de simbólico em seu destino.

III

A tragédia, através do êxtase dionisíaco descarregado na aparência apolínea, é capaz de levar ao consolo metafísico "de que a vida, no fundo das coisas, apesar de toda a mudança das aparências fenomenais, é indestrutivelmente poderosa e cheia de alegria". ${ }^{34}$ Por isso, a tragédia é dotada de uma força poderosa de afirmar a vida, salvando, por meio da arte, o indivíduo da náusea: "Ele é salvo pela arte, e através da arte salva-se nele - a vida". ${ }^{35}$ Assim, aquela disposição ascética, já mencionada, proveniente do retorno à individuação cotidiana após o êxtase dionisíaco, pode ser superada pela arte, e apenas por ela; quando o pathos dionisíaco se descarrega em formas e aparências apolíneas, então a vida pode ser afirmada, deixando de lado a negação do querer. A arte é a salvação da náusea do homem dionisíaco, pois transforma o horror em sublime e o absurdo em cômico: 
Aqui, neste supremo perigo da vontade, aproxima-se, qual feiticeira da salvação e da cura, a arte; só ela tem o poder de transformar aqueles pensamentos enojados sobre 0 horror e o absurdo da existência em representações com as quais é possível viver: são elas o sublime, enquanto domesticação artística do horrível, e o cômico, enquanto descarga artística da náusea do absurdo. ${ }^{36}$

Essa salvação do horror e da náusea pela arte estaria também presente em Hamlet?

O último ato da tragédia talvez possa nos indicar um processo análogo, quando o protagonista enfim executa sua vingança; após toda a negação que demonstrara ao longo da peça, ele finalmente age, de modo que parece ter superado a náusea e a inação. Embora demonstre uma presciência do desfecho trágico que o espreita, Hamlet se deixa levar pelo curso do destino, sabendo que a natureza é imutável: "existe uma providência especial na queda de um pardal. Se for agora, não está para vir; se não está para vir, é esta a hora; e se esta é a hora, virá de qualquer modo". ${ }^{37}$ Trata-se, novamente, da sabedoria dionisíaca, a qual revela que a verdadeira essência das coisas é eterna e imutável; mas, agora, ela assumiu uma nova feição, pois o príncipe não se deixa mais abater pela negação da vontade. Nessa última cena, ele está pronto para agir, preparado para tudo, e enfrenta conscientemente seu destino, conforme observa Bloom: "Hamlet suspende o próprio luto durante $o$ intervalo da ação entre $o$ quarto e o quinto atos" ${ }^{38} 0$ crítico ainda afirma que o personagem "parece curado" nesse último ato, e vai de encontro à morte obstinadamente. $^{39}$

Ao analisar o Édipo em Colono de Sófocles, Nietzsche pondera que "o herói, em seu comportamento puramente passivo, alcança sua suprema atividade, que se estende muito além de sua vida, enquanto que a sua busca e empenho conscientes apenas o conduziram à passividade".$^{40}$ Percebemos isso em Hamlet - enquanto o príncipe se atormentara incessantemente em agir, lutando (ou tentando lutar) contra sua disposição ascética, nada lograra. Porém, a partir da transformação 
sofrida na passagem do quarto para o quinto ato, em que ele resignadamente se deixa levar pelo destino de modo imperturbável, então é possível agir; então ele enfim consuma sua vingança, em uma repentina sucessão de acontecimentos que, como afirma Nietzsche, se estenderão muito além de sua vida. É como se Hamlet se abstivesse de tentar enfrentar o "mar de calamidades", ou de "colocar o mundo nos eixos", para apenas seguir o fluxo inexorável do destino. Como diz Oswaldo Giacóia, a verdade dionisíaca "revela que, a despeito de sua agitação frenética e ruidosa, só produzimos fugazes efeitos de superfície, que nada alteram o essencial das coisas - nem o curso do mundo, nem nosso próprio destino [...]". ${ }^{41}$ Essa constatação, no entanto, não angustia mais Hamlet, como outrora: ao contrário, ele percebe e se conforma com a fatalidade; a sabedoria dionisíaca não causa mais náusea e sim uma espécie de acomodamento ao inevitável, através do qual a ação se torna possível. $\mathrm{Na}$ incapacidade de alterar a essência eterna e imutável das coisas, resta ao herói resignar-se a agir na superfície; nessa resignação consiste a suspensão do luto mencionada por Bloom, a serenidade com que Hamlet se depara com o destino no último ato.

Vejamos, pois, o que se passa no ato $V$ da peça. Em sua primeira cena, a morte é novamente abordada, embora de modo um tanto distinto do que na cena 3 do ato I, da qual falamos acima. Ao voltar da viagem à Inglaterra (onde uma armadilha preparada pelo rei o aguardava), Hamlet reaparece em um cemitério, ao lado de Horácio, onde observam o trabalho de um coveiro. Após um breve diálogo com este último, o príncipe encontra o crânio do falecido bobo da corte, e pondera sobre a inexorabilidade da morte, que segue seu curso natural, a despeito dos expedientes humanos. Reis, generais, advogados, políticos, ou um simples bobo da corte, todos são iguais após a morte; todos serão igualmente devorados pelos vermes, independentemente dos cargos e funções que exerceram em suas vidas cotidianas, na superfície do principium individuationis. Tudo não passa de "ilusões de glória"; todas as idiossincrasias geradas pela individuação são apenas ilusão passageira. 
Tomando em suas mãos o crânio do bufão da corte, Hamlet lhe indaga:

Que fizeram de teus sarcasmos, de tuas cabriolas, de tuas canções, de teus rasgos de bom humor, que faziam toda a mesa prorromper em gargalhada? Nada, nem uma só graça sequer para ridicularizar sua própria careta? Tudo descarnado? Vai agora ao toucador de minha Senhora e dize-lhe que, embora coloque a mais espessa camada de pintura, nada impedirá que venha ela para aqui. Faze-a rir com isso! ${ }^{42}$

Ao esperar do bobo que faça a rainha rir com a recordação dessa verdade indesejável, está presente em Hamlet aquela capacidade artística de descarregar o pathos dionisíaco na forma de imagens prazerosas. 0 bufão, através de sua arte, é capaz de fazer rir até mesmo com a constatação da falta de sentido da vida na individuação; é capaz de arrancar gargalhadas da rainha ao lembrá-la que irá, inevitavelmente, morrer, e que todas as suas invectivas no sentido de camuflar a passagem inexorável do tempo (por meio de seus cosméticos) serão absolutamente baldadas. Através da bela aparência apolínea com que se traveste, a morte pode se tornar cômica; o que o príncipe faz é recomendar ao bufão que descarregue a náusea da verdade dionisíaca em forma cômica. "Faze-a rir com isso!", diz ele ao velho companheiro, após constatar o absurdo da existência na individuação, onde os homens pretendem se distinguir através de devaneios e ilusões de glória, mas, ao final, são reduzidos ao mesmo pó do qual vieram. Percebe-se aqui uma transformação artística do absurdo em cômico, constituindo aquilo que Nietzsche chama na seção sete de $O$ nascimento da tragédia de satírico.

No entanto, não é apenas no ato $V$ que percebemos essa descarga artística da náusea em forma cômica, pelo contrário: Hamlet parece apresentar esse aspecto satírico no decorrer da peça toda. Ora, se a arte (e, mais especificamente, a arte da tragédia, fruto da união entre apolíneo e dionisíaco) é a solução apontada por Nietzsche para superar o estado de náusea, Hamlet é, certamente, um artista. Não seria descabido, talvez, 
supor que seu fazer artístico ao longo dos primeiros atos seja uma espécie de gérmen da aceitação do destino a que o personagem chegará na última cena. Afinal, para Nietzsche, "na medida em que o sujeito é um artista, ele já está liberto de sua vontade individual e tornou-se, por assim dizer, um médium através do qual o único Sujeito verdadeiramente existente celebra a sua redenção na aparência". ${ }^{43}$ Sendo o artista que é, o príncipe dinamarquês se libertara gradativamente das fronteiras impostas pela individuação, tornando-se o veículo pelo qual a essência dionisíaca do mundo se manifesta. Sua atitude no último ato representa o estágio final desse processo: "agora ele [o artista] é ao mesmo tempo sujeito e objeto, ao mesmo tempo poeta, ator e espectador". ${ }^{44}$

Pensemos, pois, no que consiste esse fazer artístico de Hamlet que estamos apontando. Em primeiro lugar, ele representa um personagem dentro da peça, passando-se por louco e, ao que tudo indica, convence todos os demais com sua encenação. Essa loucura simulada se distingue da hipocrisia generalizada que acometera a corte dinamarquesa: esta é causada pelas práticas sociais e políticas próprias da individuação; aquela pode ser entendida como uma descarga do pathos causado pelo saber dionisíaco, isto é, pela constatação do absurdo da existência, e que se materializa através de uma forma apolínea. Quando Hamlet encena seu papel de louco, ele é como o sátiro coreuta descrito por Nietzsche que se encontra na gênese da tragédia. ${ }^{45}$ Portanto, é através da aparência (apolínea) que Hamlet traz à luz sua angústia pela vida, seu sentimento de nojo (dionisíaco), do mesmo modo que o sátiro grego.

Em diversas circunstâncias o príncipe se vale de um discurso satírico, quase sempre em situações em que trata, de alguma forma, do tema da morte - o que nos remete, novamente, ao preceito de Sileno. Melhor seria morrer e, não por acaso, a morte é um tema frequente nas falas de Hamlet. ${ }^{46}$ Talvez, essa repetição, bem como a naturalidade com que ela se dá, sejam consequências dessa negação da vida, própria da sabedoria dionisíaca. No monólogo do "ser ou não ser" analisado acima, tal sentimento de horror se convertera em sublime; na cena do 
cemitério, com o crânio nas mãos, é sugerida uma possibilidade cômica ("Faze-a rir com isso!"). Também de forma cômica é tratada a morte do conselheiro Polônio: "este conselheiro está agora muito quieto, muito calado e muito grave; ele que foi em vida um sujeito tagarela e parvo". $47 \mathrm{~A}$ constatação do quão absurdas podem ser a vida e a morte, e como esta última rompe com as convenções sociais e políticas da primeira; a ironia acerca do presumido destino de um rei, devorado por um verme, a "circular ao longo das tripas de um mendigo"48. ou mesmo nas já citadas cenas do cemitério e da morte de Polônio; tudo isso é transfigurado em uma aparência de comicidade, através da qual a náusea pela existência se manifesta. Não nos esqueçamos que as atitudes cômicas do personagem fazem parte de sua encenação como louco e, portanto, é de um ator que estamos falando; o próprio personagem Hamlet é um ator dentro da peça escrita por Shakespeare, um ator que também é dramaturgo de seu próprio personagem, improvisado sucessivamente, de acordo com as circunstâncias que lhe aparecem.

Ademais, Hamlet reescreve e dirige um espetáculo teatral, $A$ ratoeira, que pouco ou nada tem a ver com a peça em que se baseia, e que o príncipe solicitara aos atores que representassem. Embora diga ao ator que acrescentará apenas algumas linhas ao texto, é possível que, ao final, $A$ ratoeira seja uma peça inteiramente nova, surgida do engenho de Hamlet. Evidentemente, há uma clara distinção entre essa peça criada pelo príncipe (fruto da era elisabetana) e as tragédias áticas analisadas por Nietzsche em $O$ nascimento da tragédia. Não se trata, portanto, de dizer que $A$ ratoeira seja uma tragédia tal qual as de Ésquilo e Sófocles, por exemplo. 0 que pretendemos mostrar é o quanto o personagem lança mão de recursos artísticos no decorrer da história. Shakespeare faz questão de mostrar Hamlet instruindo os atores, até mesmo acerca do modo como devem atuar; também ressalta o fato de o príncipe nutrir grande simpatia por eles e recomendar que sejam tratados com grande honra em sua estadia na corte. Pelas palavras de seu personagem, o Bardo afirma que o objetivo da arte dramática "tanto em sua origem como nos tempos que 
correm, foi e é o de apresentar, por assim dizer, um espelho à vida; mostrar à virtude suas próprias feições, ao vício sua verdadeira imagem e a cada idade e geração sua fisionomia e características". ${ }^{49}$ Ou seja, o teatro, para Shakespeare, possuía a função de mostrar a verdade através da representação artística. Ainda que se trate de uma verdade no sentido cotidiano e factual da individuação, e não daquela verdade metafísica e dionisíaca da qual Nietzsche fala; ainda assim, é digno de nota o fato de que o poeta concedia tamanho poder ao teatro. Não é por acaso que tal seja o artifício de que Hamlet lança mão para tirar a prova das palavras do fantasma de seu pai, das quais ele ainda suspeitava até aquele momento.

Por fim, na última cena, percebemosnovamente a presença do fenômeno do sublime, isto é, a "domesticação artística do horror". Já tivemos ocasião de mencionar o fato de que Hamlet, em seus monólogos, se assemelha a um poeta lírico, bem como que o príncipe parece curado da náusea no último ato. Pois bem, a cena final da tragédia shakespeariana nos fornece alguns indícios que podem ratificar nossa leitura de que 0 príncipe supera a náusea por meio da arte, tal como Nietzsche afirma ser possível. Após o retorno da Inglaterra, o príncipe encontra em solo dinamarquês uma nova artimanha engendrada pelo rei, na forma de um duelo aparentemente amistoso, mas que encobre os reais planos de Cláudio e Laertes de assassinar Hamlet. No entanto, após a descoberta do embuste do florete desprotegido, e dos envenenamentos acidentais da rainha e do próprio Laertes, a verdade irrompe, culminando em um grande morticínio que deixa o palco repleto de cadáveres. 0 horror dessa cena bem pode ser entendido como uma representação artística do próprio horror dionisíaco, o qual se manifesta aqui em uma aparência apolínea. Pois, segundo Nietzsche, o mito narrado na tragédia serve como veículo da sabedoria dionisíaca, uma vez que é reinterpretado por essa última, a qual "se apossa do domínio conjunto do mito como simbolismo de seus conhecimentos". ${ }^{50}$ Portanto, na tragédia, o mito não deve ser entendido em seu sentido literal, como uma possível realidade histórica, mas sim como alegoria de verdades mais profundas, isto é, da verdade dionisíaca. 
Ademais, a sabedoria dionisíaca cobra o seu preço àquele que a possui: pois atingi-la representa exceder os limites propriamente humanos, o que acarreta a destruição daquele que a alcança. E quem cobra esse preço é Apolo, enquanto endeusamento da individuação, isto é, "a observação das fronteiras do indivíduo, a medida no sentido helênico" ${ }^{51}$ Apolo interpreta o passado de deuses titânicos dos gregos como excessos e desmedida, os quais devem ser punidos com a destruição. Por isso Prometeu deve ser devorado por abutres, $\mathrm{e}$ por isso Édipo é incestuoso e parricida, acabando por automutilar-se. Tal é o preço que essas figuras pagam por sua sabedoria que ultrapassa as medidas. Também Hamlet, enquanto homem dionisíaco, paga o preço pela desmedida de sua sabedoria; em sua jornada, ele também se torna autor de crimes diversos (os assassinatos diretos e indiretos de vários personagens) e, por fim, também ruma à própria destruição, precipitando-se na loucura e na morte. Além disso, Nietzsche considera que a sabedoria dionisíaca "é um horror antinatural" e "um crime contra a natureza" ${ }^{52}$ Sendo a sabedoria uma atitude antinatural, uma violência com a qual se obriga a natureza a revelar seus segredos, o sábio dionisíaco só pode ser, ele próprio, um transgressor da natureza, e isso transparece no mito, já que este é o veículo da sabedoria dionisíaca: novamente temos o exemplo de Édipo, incestuoso e parricida. Seus sacrilégios são um reflexo do caráter antinatural de sua sabedoria. E, novamente, podemos aplicar esse raciocínio a Hamlet: não só seus crimes já mencionados, mas sua atitude violenta para com sua mãe é frequentemente vista como antinatural e sacrílega. ${ }^{53}$ Assim, o horror da última cena pode ser visto como o ápice desse processo de desagregação do herói trágico e de seu mundo. É o mito servindo de veículo para a sabedoria dionisíaca.

No entanto, em meio a essa cena terrível, podemos notar uma domesticação artística do horror em sublime no diálogo entre Hamlet e Horácio. Este último parece ter sido tomado também por aquele nojo já mencionado, e por isso cogita o suicídio (assim como o próprio Hamlet o cogitara anteriormente e assim como Ofélia o cometera - todos os três, vítimas da 
mesma náusea). Mas o amigo lhe tira a taça envenenada das mãos, suplicando que suporte as adversidades da vida por mais algum tempo, e que conte sua história. Horácio é aquele que acompanhou Hamlet em seu percurso desde o princípio, e é o único além do príncipe a conhecer a corrupção em que se fundara aquele reinado que acabava de se despedaçar; por isso, ele também é o único capaz de desempenhar a tarefa de transmitir essa história trágica para o próximo reino da Dinamarca. Hamlet impede o suicídio do amigo, não por amor à vida, ou por horror à morte, mas sim para que sua história seja contada para a posteridade; o que ele tem em vista é a representação que será feita de sua vida e de seus atos. Doravante, ele será como um herói de tragédia, cujas façanhas são contadas através das gerações, e cuja representação feita pelos poetas sobrevive à sua própria existência. Sua trajetória servirá de ensinamento para os tempos futuros tal qual as trajetórias de Édipo ou Prometeu. Em seu último suspiro, Hamlet está a considerar a dimensão artística de sua vida e de sua morte: mais do que nunca, ele é um personagem de si mesmo.

Por todas essas razões sobre as quais discorremos até aqui, acreditamos poder sustentar que o príncipe da Dinamarca, através de seu fazer artístico, supera o estado de náusea em que esteve submerso ao longo da tragédia. Não podemos desconsiderar que Hamlet seja um homem de teatro: escreve, dirige, atua; é autor e intérprete de seu próprio espetáculo, o qual se encontra dentro da peça escrita por Shakespeare. E, sendo ele um homem dionisíaco, como Nietzsche atestara, o que ele encontra ao final do caminho percorrido é exatamente aquilo que é apontado pelo filósofo alemão: o consolo metafísico propiciado pela arte, o mesmo que na Grécia Antiga salvava a vida da náusea negadora da vontade, causada pelo conhecimento da verdade. O Hamlet da última cena já não padece da náusea, já não sofre os efeitos colaterais do saber dionisíaco; conhece seu destino, bem como sua inexorabilidade e segue o fluxo dos acontecimentos. Ele está pronto para a vida e para a morte. Igualmente, podemos inferir que a peça Hamlet, como um todo, é uma tragédia da redenção diante do 
horror e superação da náusea, de modo que seu herói trágico é um homem dionisíaco por excelência - e não por acaso Nietzsche o utiliza como exemplo na explanação de sua tese acerca do nascimento da tragédia.

Mateus Masiero é doutorando em filosofia pela UNICAMP. Newton Amusquivar Jr. é doutorando em filosofia pela UNICAMP.

${ }^{1}$ NIETZSCHE, F. O drama musical grego. In: A visão dionisíaca do mundo, e outros textos de juventude. Tradução de Marcos S. P. Fernandes e Maria C. dos Santos; revisão de Marcos Casanova. São Paulo: Martins Fontes, 2005, p. 48.

${ }^{2}$ Idem. Sócrates e a tragédia. In: A visão dionisíaca do mundo, e outros textos de juventude. Op. cit., p. 89.

${ }^{3}$ Ibidem, p. 91.

${ }^{4}$ Idem. $O$ nascimento da tragédia ou Helenismo e pessimismo. Tradução de J. Guinsburg. São Paulo: Companhia das letras, 2007, seção 10, p. 67.

${ }^{5}$ Ibidem, seção 10, p. 66.

${ }^{6}$ Ibidem.

7 SHAKESPEARE, W. Hamlet. In: Obra completa. Tradução de F. Carlos de Almeida Cunha Medeiros. Rio de Janeiro: José Aguilar, 1969, v. 1, ato I, cena 2, p. 538.

${ }^{8}$ NIETZSCHE, F. Op. cit., seção 1, p. 28.

${ }^{9}$ SHAKESPEARE, W. Op. cit., ato I, cena 2, p. 538.

${ }^{10}$ NIETZSCHE, F. Op. cit., seção 10, p. 67.

${ }^{11}$ KOTT, J. Shakespeare nosso contemporâneo. Tradução de Paulo Neves. São Paulo: Cosac \& Naify, 2003, p. 72.

12 BLOOM, H. Shakespeare: a invenção do humano. Tradução de José Roberto O'Shea. Rio de Janeiro: Objetiva, 2000, p. 528.

${ }^{13}$ NIETZSCHE, F. Op. cit., seção 3, p. 33. Os grifos são do original.

${ }^{14}$ Ibidem, seção 7, p. 52.

${ }^{15}$ Ibidem.

${ }^{16}$ Cf. ibidem, seção 8, p. 54-5.

${ }^{17}$ Ibidem, seção 7, p. 52.

${ }^{18}$ Ibidem, seção 7, p. 53. Grifo do original.

${ }^{19}$ SHAKESPEARE, W. Op. cit., ato I, cena 5, p. 551. Tradução ligeiramente modificada.

${ }^{20}$ NIETZSCHE, F. Op. cit., seção 7, p. 53. 
${ }^{21}$ Cf. ibidem, seção 3, p. 33-4.

${ }^{22}$ SHAKESPEARE, W. Op. cit., ato II, cena 2, p. 566.

${ }^{23}$ Ibidem, ato IV, cena 4, p. 591. Grifos nossos.

${ }^{24}$ Cf. BLOOM, H. Op. cit., p. 504.

${ }^{25}$ SHAKESPEARE, W. Op. cit., ato II, cena 2, p. 560.

${ }^{26}$ Ibidem, ato III, cena 1, p. 568.

${ }^{27}$ Ibidem.

${ }^{28}$ Ibidem.

${ }^{29}$ NIETZSCHE, F. Op. cit., seção 5, p. 41.

${ }^{30}$ Ibidem, seção 5, p. 42.

${ }^{31}$ Ibidem, seção 6, p. 47.

32 Ibidem, seção 7, p. 53.

${ }^{33}$ SHAKESPEARE, W. Op. cit., ato III, cena 1, p. 569.

${ }^{34}$ NIETZSCHE, F. Op. cit., seção 7, p. 52.

${ }^{35}$ Ibidem.

${ }^{36}$ Ibidem, seção 7, p. 53.

${ }^{37}$ SHAKESPEARE, W. Op. cit., ato V, cena 2, p. 613.

${ }^{38}$ BLOOM, H. Op. cit., p. 532.

${ }^{39}$ Cf. Ibidem, p. 531.

${ }^{40}$ NIETZSCHE, F. Op. cit., seção 9, p. 61.

${ }^{41}$ GIACÓIA, O. "O Édipo e a tragédia em Freud e Nietzsche". In: VOLOBUEF, K. (org.). Mito e magia. São Paulo: Editora da Unesp, 2011, p. 141. Talvez nesse sentido devamos, também, compreender as palavras de outro herói trágico shakespeariano, o rei Macbeth. Ao saber da morte de sua esposa, a qual se suicidara após enlouquecer (tal qual Ofélia, vale notar), o rei afirma que a vida é apenas sombra passageira, a produzir barulho e agitação (fúria) sem que haja sentido imanente algum nisso. É apenas agitação na superfície da individuação, não produzindo efeitos reais na essência das coisas. (Cf. SHAKESPEARE, W. Macbeth. In: Obra completa. Tradução de F. Carlos de Almeida Cunha Medeiros. Rio de Janeiro: José Aguilar, 1969, v. 1, ato $V$, cena 5, p. 523).

${ }^{42}$ SHAKESPEARE, W. Op. cit., ato V, cena 1, pp. 605-6.

${ }^{43}$ NIETZSCHE, F. Op. cit., seção 5, p. 44.

${ }^{44}$ Ibidem, seção 5, p 45.

${ }^{45}$ Cf. ibidem, seção 7, p. 51-2.

${ }^{46}$ A presença da morbidez nas falas de Hamlet foi também observada por Northrop Frye (Cf. FRYE, N. Sobre Shakespeare. Tradução de Simone Lopes de Mello. São Paulo: Edusp, 1992, pp. 108-109 e 113). 
${ }^{47}$ SHAKESPEARE, W. Op. cit., ato III, cena 4, p. 586.

${ }^{48}$ Ibidem, ato IV, cena 3, p. 589.

${ }^{49}$ Ibidem, ato III, cena 2, p. 571.

${ }^{50}$ NIETZSCHE, F. Op. cit., seção 10, p. 68. 0 grifo é do original.

${ }^{51}$ Ibidem, seção 4, p. 37. 0 grifo é do original.

${ }^{52}$ Ibidem, seção 9, p. 62.

${ }^{53}$ Não por acaso, Freud viu em sua postura os indícios do "complexo de Édipo". Não nos deteremos nesta questão, no entanto. 